\title{
DESCRIPTION OF A NEW LIZARD FROM LOWER CALIFORNIA.
}

\author{
BY \\ LeOnhaRd STEJNEGER, \\ Curator of the Department of Reptiles and Batrachians.
}

Cnemidophorus labialis sp. nov.

Diagnosis._Nasal in contact with second supralabial; postnasal and first supralabial not in contact; two large preanals, the largest behind; dorsal scales equal; nostril anterior to nasal suture; eight longitudinal rows of ventral plates ; femoral pores twelve to thirteen ; fronto-parietals distinct; supraoculars four; caudal scales slightly oblique.

Haвiтат.-Cerros Island, Lower California.

Type, U. S. National Museum, No. 15596 ; L. Belding, coll.

Description of type specimen.-Nostril anterior to nasal suture; three parietals ; four supraoculars ; seven supraciliares ; a freno-orbital ; two fronto-parietals; scales on middle of eyelid slightly enlarged, hexagonal; nasal in contact with second upper labial, postnasal and second upper labial being separated; posterior gular scales small, abruptly separated from the anterior, the line of demarkation between them being emphasized by the two rows nearest the latter being markedly smaller than the rest of the posterior ones; plates of the collar rather large, in several rows, the marginal largest; dorsal granules smooth, rather large ; ventral plates in eight longitudinal and thirty-one transverse rows. Two large preanals, wider than high, the posterior plate being widest. Three rows of brachials of nearly the same size; antebrachials continuous with brachials, in two rows, the outer one hardly larger; granules along posterior edge of under side of forearm but slightly enlarged. Five rows of femorals, outer largest; tibials in three rows, outer largest. Upper and lateral caudal scales slightly oblique, rather strongly keeled, and pointed posteriorly. Color above dark brown, with six longitudinal light lines and a median clay-colored band of the same shade as the top of the head; two light longitudinal lines on four limbs and three on hind limbs; under side whitish, more or less suffused with bluish, especially on the flanks.

For dimensions, see table below.

In addition to the type, there are four other specimens which agree with it in all essential points; two of them have thirteen femoral pores, while two have only twelve; two have thirty-three rows of ventrals, one has thirty-one, and one thirty; three have three antebrachial rows, 
and in these the outer is by far the largest; two have only four femoral rows. In other respects the specimens are nearly identical.

Of all our North American Cnemidophori this seems to be the most distinct species, Cnemidophorus (Verticaria) hyperythrus not even excepted. As will be seen from an enumeration of the characters by which it differs from them all, viz: the peculiar relations of the nasals and anterior labials, the arrangement of the preanals, the low number of femoral pores, twelve to thirteen, brachials in three subequal rows, femorals in only four to five rows. Of these the first-mentioned eharacter seems even to be unique in the genus, as I have seen no mention of it in the descriptions of extralimital species, and after a careful examination of about three hundred specimens of the various North American forms I can find no approach to the condition which is so eharacteristic of the present species, in all five specimens of which it is equally well pronounced. The low number of femoral pores is also well worth noting, inasmuch as it entirely destroys the usefulness of one of the sections of Boulenger's key to the species (Cat. Liz. Brit. Mus., II, pp. 360 and 361), relied upon to separate the South American species, C. ocellifer and multilineatus from the other species with eight longitudinal rows of ventral plates and the nostrils opening in the nasal. The fusion of the two posterior preanals into one wide transrersal plate seems to be another good character. It is true that this state of affairs is occasionally seen in specimens of $C$. sexlineatus or its numerous subspecies, but the occurrence is rare, hardly reaching 2 per cent. in the enormous series examined by me, while in the Cerros Island species it is normal since found equally well represented in all five specimens.

So well circumscribed is the new species that a special comparison with other forms seems entirely unnecessary.

Specimens examined.

\begin{tabular}{|c|c|c|c|c|c|c|c|c|c|c|c|c|c|c|c|c|}
\hline $\begin{array}{l}\text { U.S. } \\
\text { Nat. } \\
\text { Mus. } \\
\text { No. }\end{array}$ & Collector. & Locality. & 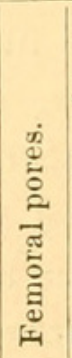 & 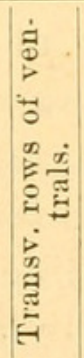 & 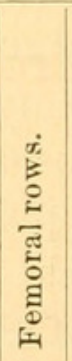 & 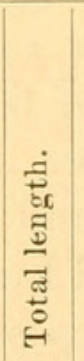 & 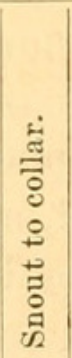 & 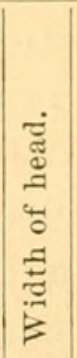 & 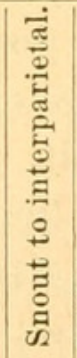 & 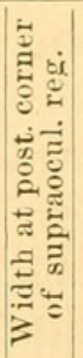 & 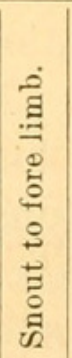 & 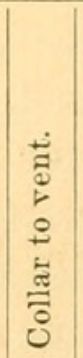 & 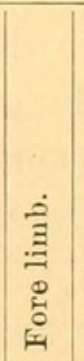 & $\begin{array}{l}\dot{\hat{\Xi}} \\
\stackrel{\Xi}{\Xi} \\
\dot{\Xi} \\
\dot{\Xi}\end{array}$ & 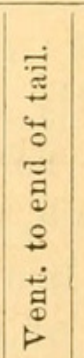 & 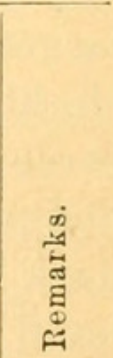 \\
\hline $\begin{array}{l}15597 \\
15598 \\
15599 \\
15600\end{array}$ & $\begin{array}{l}\text { Belding. } \\
\ldots \text { do } \ldots . \\
\ldots \text { do } \ldots . . . \\
\ldots \text { do } \\
\ldots \text { do }\end{array}$ & 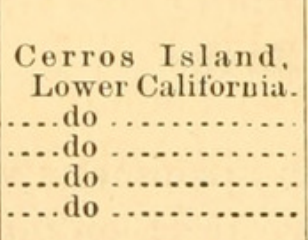 & $\begin{array}{l}13 \\
12 \\
12 \\
13\end{array}$ & $\begin{array}{l}31 \\
\\
33 \\
33 \\
31 \\
30\end{array}$ & $\begin{array}{l}5 \\
5 \\
5 \\
5 \\
4 \\
4\end{array}$ & $\begin{array}{c}m m \\
187 \\
173 \\
\cdots \\
\cdots \\
\cdots\end{array}$ & $\begin{array}{r}m m \\
18 \\
17 \\
17 \\
17 \\
18\end{array}$ & $\begin{array}{l}m m \\
8 \\
8 \\
8 \\
7.5 \\
8\end{array}$ & $\begin{array}{l}m m \\
10 \\
9.5 \\
10.3 \\
9.5 \\
9\end{array}$ & $\begin{array}{r}m m \\
5.3 \\
5.3 \\
5.3 \\
5.5 \\
\cdots\end{array}$ & $\begin{array}{l}m m \\
19.5 \\
18 \\
20 \\
18 \\
19\end{array}$ & $\begin{array}{r}m m \\
37 \\
33 \\
37 \\
34 \\
35\end{array}$ & $\begin{array}{r}m m \\
18 \\
18 \\
18 \\
18 \\
19\end{array}$ & $\begin{array}{l}37 \\
38 \\
36 \\
39\end{array}$ & $\begin{array}{c}m m \\
132 \\
123 \\
\cdots \\
\cdots \\
\cdots\end{array}$ & Type. \\
\hline
\end{tabular}




\section{$2 \mathrm{BHL}$ Biodiversity Heritage Library}

Stejneger, Leonhard. 1890. "Description of a new lizard from Lower

California." Proceedings of the United States National Museum 12(788), 643-644. https://doi.org/10.5479/si.00963801.788.643.

View This Item Online: https://www.biodiversitylibrary.org/item/53609

DOI: https://doi.org/10.5479/si.00963801.788.643

Permalink: https://www.biodiversitylibrary.org/partpdf/52732

\section{Holding Institution}

Smithsonian Libraries

\section{Sponsored by}

Smithsonian

\section{Copyright \& Reuse}

Copyright Status: Public domain. The BHL considers that this work is no longer under copyright protection.

This document was created from content at the Biodiversity Heritage Library, the world's largest open access digital library for biodiversity literature and archives. Visit BHL at https://www.biodiversitylibrary.org. 